\title{
Are Chapter 31 Military Veterans Returning to College More Likely to Choose Intrinsically-oriented Versus Extrinsically-oriented Majors?
}

\author{
Glen Miller ${ }^{1}$, Gary Blau ${ }^{1} \&$ Deborah Campbell ${ }^{1}$ \\ ${ }^{1}$ Fox School of Business \& Management, Temple University, Philadelphia, PA USA \\ Correspondence: Gary Blau, HRM Department, Fox School of Business \& Management, Temple University, \\ Philadelphia PA, 19122, USA. E-mail: gblau@temple.edu
}

Received: November 20, 2020 Accepted: December 23, 2020 Online Published: December 30, 2020

doi:10.5539/jel.v10n2p1 URL: https://doi.org/10.5539/jel.v10n2p1

\begin{abstract}
Helping military veterans successfully transition to civilian life is an important issue. Education can help with this transition. No prior studies were found on the general type of undergraduate major United States (US) Chapter 31 veterans enroll in. Chapter 31 provides tuition benefits to help entitled transitioning military veterans, with service-connected disabilities, go to college to obtain a degree. Self-determination theory (SDT) suggests two general categories of majors, intrinsic (I) versus extrinsic (E). Intrinsic motivation emphasizes doing a task for its inherent satisfaction, while extrinsic motivation targets doing the same task to achieve external rewards, such as compensation. Archival data was analyzed using small samples of undergraduate Chapter 31 military veterans in 2016, 2018 and 2020. Overall, the results supported the research question, i.e., Chapter 31 veterans will be more likely to choose intrinsically motivating versus extrinsically motivating college majors. Results, including limitations and suggestions for future research are discussed.
\end{abstract}

Keywords: chapter 31 United States military veterans, self-determination theory, extrinsic motivation, college major

\section{Introduction}

\subsection{Introduce the Problem}

As military veterans in the United States (U.S.) leave the military and transition to civilian life, they can face many challenges. The Transitioning to Civilian Life Scale (TCLS) measures three general factors that are part of an overall transition for a veteran to become a civilian: psychosocial well-being, economic well-being, and physical health (Weiss, Rubin, \& Graeser, 2019). The economic well-being factor contains items asking about stable finances; housing quality; job stability; future career; and getting the education needed. As part of their transition, research has shown that veterans may enroll in college (Rumann \& Hamrick, 2010) or community college (Evans, Pellegrino, \& Hoggan, 2015). Some transitioning military veterans have been in prior combat situations or combat zones, and of these veterans, some have been wounded or injured. The Vocational Rehabilitation and Employment (VR\&E) program is authorized under Title 38, U.S. Code, Chapter 31 (U.S. Department of Veterans Affairs, 2018). It is referred to as the Chapter 31 program and assists entitled veterans with service-connected disabilities and an employment handicap to prepare for, find, and maintain a job. These military service-connected disabilities are often due to being wounded or injured in a combat zone (Miller, Hall, Agyapong, Kelly, \& McArthur, 2011), and can also include psychological disabilities, such as Post Traumatic Stress Disorder (PTSD).

To be eligible for Chapter 31 benefits, a military veteran must file a claim showing a service-connected disability rating of at least 10 percent with a serious employment handicap, or 20 percent or more disability rating with an employment handicap (U.S. Department of Veterans Affairs, 2018). This rating is generally determined by medical test results and/or a doctor's report and VA claim exam. The rating can cover such areas as mobility-related (e.g., assisted walking or wheelchair); physical limitations (e.g., bending, carrying, climbing ladders/stairs, grasping, pulling/pushing, sensitivity to bright lights or loud noises), or if frequent rest breaks are required. A Vocational Rehabilitation Counselor typically works with the veteran to determine eligibility and develop a plan, which can include enrolling in college to obtain a degree. Chapter 31 provides benefits to help these entitled transitioning service members go to college to obtain a college degree. The signed agreement between the veteran and Veterans Administration is used as part of the admission process to college. A disability 
statement, typically validated by a college's Disability Resource Services Center letter, can affect the classroom learning and testing conditions for a Chapter 31 veteran in an Instructor's class. For example, this could include: alternate format textbooks, prior class access to any material to be projected on a screen or written on a board during class, more time for examinations, and testing in a distraction-reduced environment. The purpose of this study was to investigate if these Chapter 31 veterans returning to college were more likely to choose a more intrinsically-oriented versus a more extrinsically-oriented undergraduate college major.

\subsection{Explore Importance of the Problem}

The United States Department of Veterans Affairs (2016) estimated that by 2021, there will be about 5.1 million veterans who were on active duty after September 10, 2001 (Post-9/11 Veterans). Of those Post-9/11 Veterans, it was further estimated that only $32 \%$ will have a bachelor's degree or higher. In their sample of Post-9/11 Veterans, Morgan, Desmarais and Neupert (2017) found positive self-reported relationships of increased education to happiness and health. In their qualitative study, Bagby, Barnard-Brak, Thompson and Sulak (2015) found that student veterans' university-related educational experiences, such as joining a social network, and interacting with same-major peers and faculty contacts, were helpful as they transitioned from military to civilian life. Prior studies of veterans returning to college or community college have typically focused on student transition concerns, much of which was related to policies that complicated re-enrollment, such as lapses in student insurance, cancellation of financial aid, or being off-sequence for infrequently offered courses (e.g., Rumann \& Hamrick, 2010). Other studies have argued the need for increased support to help returning-to-college veterans, such as having access to student veterans' organizations, additional mentoring, or veterans' resource centers (e.g., Evans et al., 2015). However, the authors were unable to find any prior research investigating the type of college major Chapter 31 veterans were more likely to choose upon enrolling. Finding the right major, leading to a stronger job fit after graduation, would be important to help such veterans make a smoother transition back to civilian life. General research with college graduates supports this right major-stronger job success link (Ellison, 2019). Prior research has found that academic motivation, whatever the major, is a significant determinant of a college student's scholastic performance and happiness (Niemiec \& Ryan, 2009).

\subsection{Relevant Scholarship}

While there is much research on the negative outcomes experienced as a result of combat, such as PTSD (Pless, Kaiser, Cook, Glick, \& Moye, 2019), or loneliness and depression (Martin \& Lucas Hartley, 2017), studies have also found that there can be positive outcomes, such as post traumatic growth (Blau \& Miller, 2019), and resilience (Green, Calhoun, Dennis, \& Beckham, 2010). Military veterans successfully transitioning to being productive employees possess such qualities as leadership, teamwork, maintaining control under pressure, integrity, and being goal-oriented (Hammock, 2015). Such qualities/factors can be integrated into self-determination theory or SDT (Ryan \& Deci, 2000). SDT focuses on intrinsic motivation, i.e., doing a task for its inherent satisfaction, and humans' fundamental needs for competence, autonomy and relatedness. This can be contrasted to extrinsic motivation, which targets doing the same task to achieve external rewards, or avoid punishment (Ryan \& Deci, 2000). Being self-determined is defined (Ryan \& Deci, 2000, p. 76) as a human's "natural inclination toward assimilation, mastery, spontaneous interest, and exploration." We believe that Chapter 31 veterans, given the above-mentioned qualities they possess, will be more likely to choose intrinsically versus extrinsically motivating college majors.

Prior work has classified college majors as being more intrinsically (I) versus more extrinsically (E) oriented. For example, business students with such majors as accounting, business management, finance, and marketing, with a general emphasis on maximizing profits, have a higher extrinsic value orientation than education majors, who are more intrinsically motivated (Vansteenkiste, Duriez, Simons, \& Soenens, 2006). Engineering-related and technology-related majors, because of their generally higher paying jobs, tend to attract more extrinsically-motivated students (Garcia, 2019). Yu and Levesque-Bristol (2018) argued that all science-related majors, including natural sciences, such as biology, chemistry and physics, as well as social sciences, such as psychology and sociology, and their application to social work, computers, and human resources, should be more intrinsically motivated. This intrinsic motivation would also extend to health-related majors, such as nursing, kinesiology, public health, and therapeutic recreation. In addition, the humanities, since they nurture human inquisitiveness and interest should be higher on intrinsic motivation (Gonzalez-Cutre, Sierra, Ferriz, \& Hager, 2016). Humanities' majors would include: foreign languages, religion, art, music, history, political science, geography, English and philosophy (Ayers, 2009). 


\subsection{Research Question}

In the absence of any prior research, and applying SDT to Chapter 31 veterans, this study posed the following research question (RQ):

$R Q$-Chapter 31 military veterans will be more likely to choose intrinsically motivating versus extrinsically motivating college majors.

\section{Method}

\subsection{Sample and Procedure}

Student records from a large, urban Mid-Atlantic public university were used. As part of its normal enrollment procedures, the University keeps track of military veterans who enroll in different programs of study. This data includes the veteran's name, contact information, chapter code description, major, and college. Only the name, chapter code and major were used for study analyses. Chapter 31 was the only chapter code description used in this study. As noted above, it assists entitled military veterans with service-connected disabilities and an employment handicap to prepare for, find, and maintain a job by providing tuition benefits. Chapter 31 student university enrollees constituted a small fraction of the University's student military veterans (less than $5 \%$ in any year analyzed), and only undergraduate student records were used. The number of Chapter 31 graduate students was less than $1 \%$ of the University's student military veterans. Archival data were used for this study, and data was available for the years 2016, 2018 and 2020. A two-year gap was used to eliminate analyzing the same student - same major record within the four-year period (any duplicates were deleted). The only exception to using a student more than once is if their major changed across the surveys. If a student did change majors, regardless of general I versus E category, this data was included. There were several examples of such students changing majors. There was no clear pattern of students' changing from an I major to an E major or vice-a-versa.

\subsection{Measures}

Gender was identified using the name of the respondent. This information was used to give male versus female percentage breakdown in any year. .

Chapter 31 was the only chapter code used. This code is assigned once it is determined the veterans meets the requirements. As noted above, a military veteran must have a Veteran's Administration service-connected disability rating of at least 10 percent with a serious employment handicap, or 20 percent or more with an employment handicap (U.S. Department of Veterans Affairs, 2018). A Vocational Rehabilitation Counselor typically works with the veteran to determine eligibility and develop a plan, which can include enrolling in college to obtain a degree. The signed agreement between the veteran and Veterans Administration is used as part of the admission process to college.

Student major listed for each veteran in a given year. The majors were coded I for intrinsically motivated or E for extrinsically motivated. Coding was based on the literature review. Intrinsic motivation involves doing a task for its inherent satisfaction, and humans' fundamental needs for competence, autonomy and relatedness (Ryan \& Deci, 2000). Meanwhile, extrinsic motivation for doing the same task focuses more on achieving external rewards, such as compensation. Business majors (except human resource management), engineering-related and technology-related majors (unless from a science college) were coded E (Garcia, 2019; Vansteenkiste et al., 2006). All science-related majors, including natural, social, and applied science, as well as health-related majors, were coded I (Yu \& Levesque-Bristol, 2018). All humanities majors were coded I (Ayers, 2009; Gonzalez-Cutre et al., 2016). Coding results are reported in the Tables. All authors checked the coding.

Qualitative data. The first author is a military combat veteran and over a 12-year period has collected data via interviews with and podcasts on combat veterans. The third author was the Student Veterans Association (SVA) Faculty Advisor, from 2010 to 2019, at the University where the data were collected. Their observations are reported in the Discussion section.

\subsection{Data Analyses}

All data were re-coded in SPSS-PC (2015). Chi-square analyses, using the MedCalc (2020) comparison of proportions, were performed for each year to see if there was significant difference in the percentage of Chapter 31 veterans who had Intrinsic-oriented (I) versus Extrinsic-oriented (E) majors. A significance level of $p<.10$ (two-tailed) was used as the cutoff for statistical significance. It has been asserted that $p=.10$ is "an appropriate default level of confidence" (Hopkins, Marshall, Batterham, \& Hanin, 2008, p. 6). 


\section{Results}

\subsection{Test of Research Question}

Tables 1, 2 and 3 show the breakdown of undergraduate majors for Chapter 31 veterans. Table 1 reports 2016 data, Table 2 reports 2018 data and Table 3 reports 2020 data. Specific majors are listed alphabetically for each table. After each major an I for Intrinsic Motivation or E for Extrinsic Motivation is given. There are several points to note about classifying specific majors into I versus E categories, beyond what has already been noted. In Table 3, Computer Science was categorized as an I major because this degree is from the College of Science (as noted), and would be considered an applied science major (Yu \& Levensque-Bristol, 2018). If the major was based in the Business School (e.g., Management Information Systems, as in Table 1) it would have been classified as an E major. Also, in Table 3, Sport \& Recreation Management is categorized as an I major. Yu and Levensque-Bristol (2018) found that sport-science majors, as part of a more general category, had significantly higher self-determination (intrinsic) motivation than business/management/finance majors. The Chi-square results across the three tables supported the research question, Chapter 31 veterans were more likely to choose intrinsically motivating versus extrinsically motivating college majors. In addition, a gender analysis for each table showed that at least $85 \%$ of the respondents were male in a given year.

Table 1. 2016 undergraduate majors for chapter 31 veterans

\begin{tabular}{|c|c|c|}
\hline Major (I versus E) ${ }^{\mathrm{a}}$ & Frequency & Percent \\
\hline Accounting (E) & 2 & 6.3 \\
\hline Advertising $(\mathrm{E})$ & 1 & 3.1 \\
\hline African American Studies (I) & 1 & 3.1 \\
\hline Art (I) & 1 & 3.1 \\
\hline Biology (I) & 1 & 3.1 \\
\hline Business Management (E) & 1 & 3.1 \\
\hline Career and Technical Education (I) & 1 & 3.1 \\
\hline English (I) & 1 & 3.1 \\
\hline Film and Media Arts (I) & 1 & 3.1 \\
\hline Finance $(\mathrm{E})$ & 1 & 3.1 \\
\hline Geography/Urban Studies (I) & 1 & 3.1 \\
\hline Kinesiology (I) & 4 & 12.5 \\
\hline Management Information Systems (E) - Business & 1 & 3.1 \\
\hline Marketing (E) & 1 & 3.1 \\
\hline Media Studies and Production (I) & 1 & 3.1 \\
\hline Public health (I) & 2 & 6.3 \\
\hline Religion (I) & 1 & 3.1 \\
\hline Sec Ed-English Ed (I) & 1 & 3.1 \\
\hline Social Work - Undergraduate (I) & 5 & 15.6 \\
\hline Theory - Music (I) & 1 & 3.1 \\
\hline Therapeutic Recreation (I) & 1 & 3.1 \\
\hline Undeclared-Education (I) & 2 & 6.3 \\
\hline Total & 32 & 100.0 \\
\hline
\end{tabular}


Table 2. 2018 undergraduate majors for chapter 31 veterans

\begin{tabular}{|c|c|c|}
\hline Major (I versus E) ${ }^{\mathrm{a}}$ & Frequency & Percent \\
\hline Accounting (E) & 1 & 2.4 \\
\hline Adult \& Organizational Develop (I) & 2 & 4.9 \\
\hline Athletic Training (I) & 1 & 2.4 \\
\hline Biology (I) & 1 & 2.4 \\
\hline Business Administration (E) & 2 & 4.9 \\
\hline Business Management (E) & 3 & 7.3 \\
\hline Chemistry (I) & 1 & 2.4 \\
\hline Construction Mgt Tech (E) & 1 & 2.4 \\
\hline Electrical Engineering $(\mathrm{E})$ & 1 & 2.4 \\
\hline Facilities Management (I) & 1 & 2.4 \\
\hline Film and Media Arts (I) & 1 & 2.4 \\
\hline Finance $(E)$ & 3 & 7.3 \\
\hline Financial Planning (E) & 1 & 2.4 \\
\hline Geography/Urban Studies (I) & 1 & 2.4 \\
\hline Human Develop Commnty Engage (I) & 1 & 2.4 \\
\hline Human Resource Management (I) & 1 & 2.4 \\
\hline International Affairs (I) & 1 & 2.4 \\
\hline Kinesiology (I) & 1 & 2.4 \\
\hline Legal Studies (I) & 1 & 2.4 \\
\hline Mechanical Engineering (E) & 2 & 4.9 \\
\hline Middle Grades Education (I) & 2 & 4.9 \\
\hline Performance - Music (I) & 1 & 2.4 \\
\hline Philosophy (I) & 2 & 4.8 \\
\hline Public health (I) & 3 & 7.3 \\
\hline Risk Management and Insurance (E) & 1 & 2.4 \\
\hline Sec Ed-English Ed (I) & 1 & 2.4 \\
\hline Social Work - Undergraduate (I) & 2 & 4.9 \\
\hline Therapeutic Recreation (I) & 2 & 4.9 \\
\hline Total & 41 & 100.0 \\
\hline
\end{tabular}

Note. ${ }^{\mathrm{a}} \mathrm{I}=$ Intrinsic-oriented, $\mathrm{n}=26(63 \%) ; \mathrm{E}=$ Extrinsic-oriented, $\mathrm{n}=15(37 \%)$; Chi-square $=5.48(1, \mathrm{n}=41), p<.02$.

Table 3. 2020 undergraduate majors for chapter 31 veterans

\begin{tabular}{lll}
\hline Major (I versus E) $^{\text {a }}$ & Frequency & Percent \\
\hline Accounting (E) & 4 & 11.1 \\
Accounting - Online BBA (E) & 1 & 2.8 \\
Advertising - Media \& Communication (I) & 1 & 2.8 \\
Biology (I) & 1 & 2.8 \\
Business Administration (E) & 2 & 5.6 \\
Business Management (E) & 2 & 5.6 \\
Chinese (I) & 1 & 2.8 \\
Comm and Social Influence (I) & 1 & 2.8 \\
Communication Studies (I) & 1 & 2.8 \\
Computer Science BS - College of Science (I) & 1 & 2.8 \\
Criminal Justice (I) & 1 & 2.8 \\
Early Child-Elem Ed ERK4 (I) & 1 & 2.8 \\
Economics BBA (E) & 1 & 2.8 \\
Electrical Engineering (E) & 1 & 2.8 \\
Engineering Technology (E) & 1 & 2.8 \\
Film and Media Arts (I) & 1 & 2.8 \\
Finance (E) & 1 & 2.8 \\
Geography-Urban Studies (I) & 1 & 2.8 \\
Human Resource Management (I) & 1 & 2.8 \\
Mechanical Engineering (E) & 1 & 2.8 \\
Psychology (I) & 2 & 5.6 \\
Recreational Therapy (I) & 2 & 5.6 \\
Social Work (I) & 3 & 8.3 \\
Sport \& Recreation Management (I) & 2 & 5.6 \\
Therapeutic Recreation (I) & 1 & 2.8 \\
Undeclared- School of Art (I) & 1 & 2.8 \\
Total & 36 & 100.0 \\
\hline
\end{tabular}

Note. ${ }^{\mathrm{a}} \mathrm{I}=$ Intrinsic-oriented, $\mathrm{n}=22(61 \%) ; \mathrm{E}=$ Extrinsic-oriented, $\mathrm{n}=14(39 \%)$; Chi-square $=3.44(1, \mathrm{n}=36), p=.06$. 


\section{Discussion}

To the authors' knowledge, this is the first study comparing the general category of majors for Chapter 31 student veterans. Across three time periods, separated by two years, chapter 31 veterans were more likely to choose intrinsically-oriented majors than extrinsically-oriented majors. These results were only minimally affected when students who had changed majors were deleted. Given the acknowledged values of military veterans, such as teamwork, leadership, integrity, and being goal-oriented (Hammock, 2015), these results are consistent with SDT, which includes a person's "natural inclination towards assimilation, mastery, spontaneous interest, and exploration" (Ryan \& Deci, 2000, p. 76). Finding a satisfying major should be useful to help such veterans make a smoother transition back to civilian life. The high percentage of Chapter 31 males found is consistent with prior research showing a high percentage of male combat veterans (Blau \& Miller, 2019). This suggests that most, if not all, Chapter 31 veterans received their service-connected disability in a combat zone.

In twelve years of working with combat veterans, the lead author, himself a combat veteran, had collected considerable interviews and podcasts data which anecdotally suggested that combat veterans entering financial, insurance or banking business-related careers were often discouraged by the internal staff competition. Another key anecdote, from the lead author, which is supported by the literature (Davis \& Minnis, 2017), was that many combat veterans have experienced high levels of teamwork, and supervision/management in life and death situations. They described not finding teamwork or even trust in some business environments. Moreover, comments from veterans described the mission continuing and being of service. For example, a non-profit organization, Team Rubicon, operates under the assumption that veterans want to continue to serve others (Brown, 2014). This is evidenced by veterans volunteering to help after natural disasters. This qualitative data supports Chapter 31 veterans being more likely to choose intrinsically-oriented majors.

From 2010 through the fall 2019, the third author was the Student Veterans Association (SVA) Faculty Advisor at the University where the data were collected. She made a number of direct observations over this time period. First, veterans were frustrated with inefficient university-level processes (Rumann \& Hamrick, 2010). Second, given their stronger teamwork and goal-orientation (Hammock, 2015), veterans were also irritated by disorganized activities, e.g., group projects, poorly structured classes or SVA activities. Third, the Chapter 31 SVA veterans were even more frustrated than the normal veteran as they were dealing with the transition issues that all veterans faced along with their disabilities. Fourth, it was important for incoming veterans to see a core group of veterans already involved in the University SVA in order for these incoming veterans to participate. Otherwise, veterans tended to seclude themselves from campus activites and turned to the local Veterans Administration organization for support. This observation reinforces the importance of a vibrant SVA being in place to continue recruiting new members (Evans et al., 2015), especially as graduating veterans naturally left the University SVA. Finally, to further validate the relevance of distinguishing I-majors versus E-majors, the Faculty Advisor found that when the top two officer positions in the University SVA were occupied by an I-major versus an E-major there was less collaboration and group cohesion.

\subsection{Study Limitations and Future Research}

This study is best regarded as exploratory given its limitations. Only very small sample sizes could be used in any one year because Chapter 31 veterans make up a tiny percentage (less than $5 \%$ ) of chapter coded veterans going to the University. Data analysis was limited to undergraduate data bcause the number of Chapter 31 veterans doing graduate work was too small to analyze. Although the Chapter 31 program assists entitled veterans with service-connected disabilities, and the high percentage of males for the Chapter 31 respondents in this study is consistent with prior research using combat zone veterans (Blau \& Miller, 2019), we could not directly assess if all Chapter 31 respondents were combat zone veterans. Given the limitations of the archival data, it was not possible to directly assess the intrinsic versus extrinsic motivation of the Chapter 31 respondents. Such an academic motivation measure is available ( $\mathrm{Yu} \&$ Levesque-Bristol, 2018) and should be used in future research. Additional demographic data, e.g., age, type of service-connected disability, discharge date from the military, and if the decision to return to college took place soon after discharge or after a period of substantial employment, were not available and could have been helpful to further understand the relationships found. Ideally, future research should track Chapter 31 respondents to see if they find job placement consistent with their major after they graduate. This job placement could identify whether it is for a profit versus non-profit organization, as well as how the job accommodates a "serious employment handicap." Chapter 31 veterans constituted only a small percentage of veterans receiving college tuition benefits. By contrast, Chapter 33 post 9/11 was the highest University chapter code description for enrolled student veterans, and compromised over 50\% of the chapter code descriptions in any year. Chapter 33 (post-9/11 GI Bill, Ch 33) pays for tuition or job training if a student veteran was on active duty after 9/10/01, for up to three years with three years of service (U.S. 
Department of Veterans Affairs, 2016). Future research could investigate if there is a systematic choice of majors for these veterans. It would also be interesting to compare different chapter code veterans, e.g., Chapter 31 versus Chapter 33, to see for example if Chapter 31 veterans took a longer break between returning and starting college than Chapter 33 students, to figure out what they wanted to major in.

\subsection{Conclusion}

The research design of this study is unique in comparing three small samples of Chapter 31 US military veterans, separated by a two-year gap, over a four-year time period, on type of undergraduate major being pursued, i.e., intrinsic versus extrinsic. The results of this study suggest that Chapter 31 respondents, perhaps because of having a continued "desire to serve", are more likely to choose intrinsic versus extrinsically-oriented majors. There has been no prior research investigating the type of major Chapter 31 veterans returning to college choose. Given the future estimated number of veterans who may be enrolling in college after deployment, it is important to help all returning veterans find a satisfying major that will help them in their transition to civilian life. A satisfying major can support the post traumatic growth of military veterans. This is particularly important if a chosen major leads to meaningful and satisfying work for the veteran.

\section{References}

Ayers, E. L. (2009). Where the humanities live. Daedalus, 138(1), 24-34. https://doi.org/10.1162/daed.2009.138.1.24

Bagby, J. H., Barnard-Brak, L., Thompson, L. W., \& Sulak, T. N. (2015). Is anyone listening? An ecological systems perspective on veterans transitioning from the military to academia. Military Behavioral Health, 3(4), 219-229. https://doi.org/10.1080/21635781.2015.1057306

Blau, G., \& Miller, G. (2019). Comparing correlates of posttraumatic growth for military veteran versus non-military veteran samples. Journal of Behavioral Health, 8(4), 143-151. https://doi.org/10.5455/jbh.20190627063836

Brown, J. (2014). Team Rubicon provides a powerful new purpose for veterans. Retrieved November 3, 2014, from https://www.govtech.com/em/disaster/Team-Rubicon-Powerful-New-Purpose.html

Davis, V. E., \& Minnis, S. E. (2017). Military veterans' transferable skills: An HRD practitioner dilemma. Advances in Developing Human Resources, 19(1), 6-13.

Ellison, R. (2019). How choosing the right major can lead to more success and less college debt. Forbes Coaches Council. Retrieved November 24, 2020, from https://www.forbes.com/sites/forbescoachescouncil/2019/12/26/how-choosing-the-right-major-can-lead-tomore-success-and-less-college-debt/?sh=9e74f6ba83e1

Evans, J. L., Pellegrino, L., \& Hoggan, L. (2015). Supporting veterans at the community college: A review of the literature. The Community College Enterprise, 2(1), 47-65. Retrieved from https://eric.ed.gov/?id=EJ1079760

Garcia, A. (2019). The most valuable college majors, ranked. Bankrate. Retrieved November 20, 2020, from https://www.bankrate.com/career/most-valuable-college-majors/

González-Cutre, D., Sicilia, Á., Sierra, A. C., Ferriz, R., \& Hagger, M. S. (2016). Understanding the need for novelty from the perspective of self-determination theory. Personality and Individual Differences, 102, 159-169. https://doi.org/10.1016/j.paid.2016.06.036

Green, K. T., Calhoun, P. S., Dennis, M. F., \& Beckham, J. C. (2010). Exploration of the resilience construct in Post Traumatic Stress Disorder severity and functional correlates in military combat veterans who have served since September 11, 2001. Journal of Clinical Psychiatry, 71(7), 823-830. https://doi.org/10.4088/JCP.09m05780blu

Hammock, R. (2015). Five traits of military veterans that make them great employees. Small Business.com Guide to Resources for Military Veterans. Retrieved November 23, 2020, from https://smallbusiness.com/employees/five-traits-of-military-veterans/

Hopkins, W. G., Marshall, S. W., Batterham, A. M., \& Hanin, J. (2008). Progressive statistics for studies in sports medicine and exercise science. Medicine \& Science in Sports \& Exercise, 40, 1-10. https://doi.org/10.1249/MSS.0b013e31818cb278

Martin, J. C., \& Lucas, H. S. (2017). Lonely, stressed and depressed: The impact of isolation on U.S. Veterans. Military Behavioral Health, 5(4), 384-392. https://doi.org/10.1080/21635781.2017.1333064 
MedCalc. (2020). Comparison of proportions. Retrieved November 20, 2020, from https://www.medcalc.org/calc/comparison_of_proportions.php

Miller, M. A., Hall, B. T., Agyapong, F., Kelly, K. J., \& McArthur, T. (2011). Traumatic noncombat-related hand injuries in U.S. troops in the combat zone. Military Medicine, 176(6), 652-655. https://doi.org/10.7205/MILMED-D-10-00408

Morgan, J. K., Desmarais, S. L., \& Neupert, S. D. (2017). An integrated model of health and happiness among post-9/11 military veterans. Military Behavioral Health, 5(3), 236-244. https://doi.org/10.1080/21635781.2017.1310681

Niemiec, C., \& Ryan, R. M. (2009). Autonomy, competence and relatedness in the classroom: Applying self-determination theory to educational practice. Theory and Research in Education, 7(2), 133-144. https://doi.org/10.1177/1477878509104318

Pless Kaiser, A. P., Cook, J. M., Glick, D. M., \& Moye, J. (2019). Posttraumatic stress disorder in older adults: A conceptual review. Clinical Gerontologist, 42(4), 359-376. https://doi.org/10.1080/07317115.2018.1539801

Rumann, C. B., \& Hamrick, F. A. (2010). Student veterans in transition: Re-enrolling after war zone deployments. The Journal of Higher Education, 81(4), 431-458, https://doi.org/10.1080/00221546.2010.11779060

Ryan, R. M., \& Deci, E. L. (2000). Self-determination theory and the facilitation of intrinsic motivation, social $\begin{array}{llll}\text { development, and } \quad \text { well-being. } & \text { American }\end{array}$ https://doi.org/10.1037/0003-066X.55.1.68

SPSS-PC (version 24). (2015). Statistical package for the social sciences. Chicago: IBM Corp.

United States Department of Veterans Affairs. (2016). Profile of Post-9/11 Veterans: 2016. National Center for Veterans Analysis and Statistics. Retrieved from https://www.va.gov/vetdata/docs/SpecialReports/Post_911_Veterans_Profile_2016.pdf

United States Department of Veterans Affairs. (2018). Vocational Rehabilitation and Employment Services: Chapter 31 U.S. Dept of Veterans Affairs. Retrieved from https://www.benefits.va.gov/VocRehab/docs/Ch31FactSheet.pdf

Vansteenkiste, M., Duriez, B., Simons, J., \& Soenens, B. (2006). Materialistic values and well-being among business students: Further evidence of their detrimental effect. Journal of Applied Social Psychology, 36(12), 2892-2908. https://doi.org/10.1111/j.0021-9029.2006.00134.x

Weiss, E. L., Rubin, A., \& Graeser, M. (2019). Transitioning to civilian life scale (TCLS): Development, reliability, and validity. Military Behavioral Health, 7(1), 57-63. https://doi.org/10.1080/21635781.2018.1540317

Yu, S., \& Levesque-Bristol, C. (2018). Are students in some college majors more self-determined in their studies than others? Motivation and Emotion, 42, 831-851. https://doi.org/10.1007/s11031-018-9711-5

\section{Copyrights}

Copyright for this article is retained by the author, with first publication rights granted to the journal.

This is an open-access article distributed under the terms and conditions of the Creative Commons Attribution license (http://creativecommons.org/licenses/by/4.0/). 